\title{
ブルーノ・タウトのジードルンク造形観の変遷 \\ －1930年代における著作をもとにした考察— \\ TRANSITION OF BRUNO TAUT'S THOUGHT ON THE DESIGN OF SIEDLUNG \\ - Observation from the writings in 1930s-
}

\author{
杉本俊多*, 金堀一郎** \\ Toshimasa SUGIMOTO and Ichirou KANEHORI
}

\begin{abstract}
Bruno Taut has worked in Berlin to design a lot of houses for workers from 1910s to the beginning of 1930s, which can be summarized into three stages, namely 1) the stage of garden city movement, 2) the stage of utopian imagination and 3) the stage of spatial formation of suburban housings around the large city. In 1930s he has written some essays on Siedlung, especially "Siedlungsmemoiren" or "Architecturlehre", from which his final stage of synthetic thought on Siedlung could be extracted through critical analysis. Namely he criticized the modern functionalism and rationalism, and came to set the ideal on the integrated organic method of design respecting the harmony between each part and total form, and also locality or tradition, which can be estimated as the critical inheritance of each stage in his thought on Siedlung.
\end{abstract}

Keywords: Bruno Taut, Siedlung, 1930s, modern architecture ブルーノ・タウト、ジードルンク、1930 年代、近代建筑

\section{1. 序}

\section{- 1-1. 研究目的と方法}

ドイツ人建築家ブルーノ・タウト(Bruno Taut:1880-1938) は 1910 年代〜1930 年代にドイツに执いて多数のジードルンク、すな わち住宅団地の設計に取り組んだことで知られる。ジードルンク (Siedlung) はそもそも、定住する、植民するといった意味の動詞 siedeln から派生した名詞であるが、1920 年代においては近代都市 の郊外住宅団地の意味を持つに至った。その概念は二十世紀初期の 建築界にお汁る成果とともに微妙な変化を示した。タウ卜は自らそ れに関与し、その概念の形成に寄与するところがあった。

本研究は夕ウトが一応のジードルンクの成果を収め、また建築思 想全般が転換期に達していた 1930 年代という時代に、タウトが表 した著述等をもとに彼のジードルンク造形観の変遷を整理し、近代 建築史上に評価し直そうとするものである。ベルリンに現存する夕 ウトのジードルンクについては、ドイッ国内において一般に高く評 価されており、文化財として調查研究、保存修復の対象ともなって いるが、社会、政治的な環境の変化もあり、その歴史的位置づけに ついてはなお多方面からの分析や見直しを必要としていると言える。 研究の方法としては文献の精查を通して思想の転換過程を分析す るというものであるが、タウトによる他の建築作品、論文等との比 較考量を通して、タウトの建築活動全般の中で改めてジードルンク を位置づけし直しつつ、総合的な評価を行うこととするり。
ブルーノ・タウトのジードルンクについての既往研究は多くあり、 ここで列挙する余裕はないが、建築思想に関しては、特に「ブルー ノ・タウト 1880-1938」展（ベルリン芸術アカデミー, 1980 年）カ タログのF．ボレリ、K．ハルトマンの論文がよく整理されている ${ }^{2)}$ 。また 1970 年代以降のモダニズム批判期を経て、近代建築全般に わたる見直しの時期に入ったと言え、ドイツ近代建築についても多 様な観点から、多数の研究書が著されており、それらにもブルー ノ・タウトについての研究が含まれている。特に「二十年代のジー ドルンク、今日まで」展（バウハウス・アルヒーフ、1984-85 年） のカタログに現代的な評価の論文がある ${ }^{3)}$ 。またドイツ統一、東西 ブロックの融和を経て、1990 年頃から研究に広がりが出てきている。 近年、ブルーノ・タウト論集を編箱した W. ネルディンガーはこれ まで比較的見過ごされてきた 1930 年代の近代主義に批判的なタウ トの論調、有機的建築論への傾向を今日的な視点から再評価す心゙き ことを指摘しているが、そこに所収の K. ハルトマンの論文は、ジ ードルンクに関して同様の視点を展開している ${ }^{4)}$ 。こではそれら も参考に、特に 1930 年代という位相に立って、改めてタウトのジ ードルンク関連の業績を再検討することを試みる。

\section{1-2. 1930 年代のジードルンク関連著作の位置づけ}

1932 年、タウトは建築設計の指導者として招かれてモスクワに移 住するが期待通りには行かずに終わる。1933 年に帰国したが、すぐ
* 広島大学大学院工学研究科社会環境システム専攻

教授・工博

** (侏住宅デザイン研究所 工学士
Prof., Graduate School of Engineering, Hiroshima University, Dr. Eng.

Institute of Residence Design Co., Ltd., Bachelor of Eng. 
さまナチスの追及を逃れて日本に滞在し、その後 1936 年にはトル コに移り、1938 年に当地で客死する。

タウトは日本滞在中に、自らの経験をもとに、ジードルンクの発

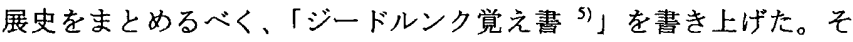
れは日本で初めて公刊され、著作集に納められた。論文の末尾には 「1936 年 8 月 24 日 少林山にて」とあり、日本を離れる直前とさ れたが、草稿は「1933 年 8 月 30 日、葉山にて」となっていて ${ }^{6) 、}$ 日本に到着してすぐに書かれている。この論文については 1934 年 7 月 9〜16 日の東京帝国大学工学部建築学科教室での「西洋の建築と 日本に対するその意義」と題する連続講演会「第四夕 ジードルン ク建築」において言及してもいる わ。タウトは日本ではジードルン ク建築の専門家という理解もされていて、1935 年 4 月 15 日に建築 学会に招かれて講演をおこなうほか、日本の建築専門雑誌や一般雑 誌にジードルンク関連の論文が紹介されている ${ }^{8)}$ 。

「ジードルンク覚え書」はタウト自ら、ドイツ時代のジードルン クを比較的冷静に整理し、実務的な経験を提示するものだったが、 ファシズム期の 1930 年代という時代相を背景にした整理であり、 そこに書かれなかったことも含めて解釈する必要がある。周知のよ うに 1920 年前後のタウトはジードルンクに対して社会改革的また 表現主義的な夢を抱いていたが、ここではそれが影を潜めている。 タウトの思想の変遷を見る際には、そのような一見、現実主義的な 様相の背後に隠されたものも含めて読み込む必要があると思われる。 そこではタウトは自らの経験から、イギリスの田園都市運動を引 き合いに出しつつ、ドイッ語の「ジードルンク」を英語 の"community"で言い替え、以下のように説明している。

「できるだけ低層の一戸建てないし連続住宅の庭付き住居、住民 の組合(Genossenschaft)（コーポラティヴ(Kooperative)）、土地投機の 防止、したがってジードルンクは都市のより良い発展の前兆 ${ }^{9)}$

"community”、つまり共同体、自治組織という社会組織の言葉と 物理的な郊外住宅団地としてのジードルンクの言葉とは次元が異な るように思われるのだが、タウトにはジードルンクの言葉の背景に 理想の社会像に対する想いがつねにあったようである。

1934 年 4 月 15 日号の『サンデー毎日』に、タウトは「日本とジ ードルンク」と題する一文を揭載し、ジードルンクを社会組織の観 点から注目すべきことを指摘している。

「ジードルンクとは、単なる家屋の集団でもなければ、都市の一 部分を指すのでもない。ジードルンクは、実に一個の経済単位なの である。しかしジードルンクは、それだけで孤立している存在では ない、つまり都市との関係をまったく断ち切られた存在というふう に解せらるべきでない。」10)

建築学会での講演も含めて、タウトは日本には、言葉を誤用した ものはあるものの、本格的な意味でのジードルンクはまだないとす る。しかし、それに類する先駆けとなるものはあるとし、「木造家 屋群、工場の労務者住宅、長屋群、二戸建て住宅、或いはいわゆる フラットやアパート、または大都市で行われている新フラットによ る細民街の整理など」、がそれだという。しかしそれらは固有のま とまりに欠け、芸術的な要素もなく、特に「組合」というものを知 らず、本格的なジードルンクとは言い難いとする。また彼は日本の ジードルンクはその風土や伝統にしたがった、ヨーロッパのものと はかなり相違するものになるとも予測しており、伝統や地域性に適
応させ、硬直した形式に拘ってはならないとする。日本滞在中には 日本の伝統的な住居について影響力のある著作を著しているが、そ れはジードルンクについてのこの柔軟な考え方とも関連する。

また、タウトが 1935-36 年に日本で一旦まとめ、トルコで書き加 えて 1938 年に出版した建築論の著書（日本語訳は『建築芸術論』） 11) が知られている。これは 1977 年にようやくドイツ語版が出版さ れた後、1930 年代のタウトの達観した境地を理解する材料として近 年、改めて注目されてきている。この著書は建築全般にわたる考察 を記述したものであるが、そこにジードルンクの設計についても多 く言及されており、分析の対象に加えることとする。

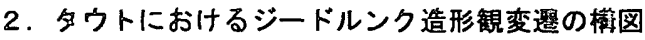

さて、1930 年代の視点に立ってタウトのジードルンク造形観の変 遷を探るべく、主に「ジードルンク覚え書」に依拠することになる わけだが、前述したようにこれには 1910 年代の初期の取り組み、 1924 年以降の大車輸の殡動は記述されているが、大戦後しばらくの 時期のことは書かれていない。しかし、ユートピア構想を描いてい たこの時期の問題は、1930 年代における最終的な思想的な到達点を 理解するには欠かせない。そこで 1910 年代〜1930 年代冒頭の夕ウ トのジードルンク造形観の変遷を吟味し、以下の三段階の変遷の構 図として捉えて構図化するに至った。すなわち、第一段階の田園都 市運動の段階、第二段階のユートピア的な集合居住観の形成段階、 第三段階の現実的な大都市郊外住宅地の空間形態形成の段階である。

\section{2-1. 1910 年代の田園都市運動の段階}

タウトは「ジードルンク覚え書」において、また前述した「西洋 の建筑と日本に対するその意義」の講演でも、イギリスの田園都市 運動がジードルンクの出発点であることを明記している。彼は $1910^{\circ}$ 年代に「ドイッ田園都市協会 (DGG：Deutsche Gartenstadtgesellschaft)」に関与し、二つの田園都市、すなわちべル リン郊外グリューナウに建設された「ファルケンベルク (Falkenberg)」(1912-14 年)とマグデブルクの田園都市コロニー「レ フォルム(Reform)」（1912-15 年、一部は第一次大戦後の 1923 年に継 続）の建設に携わった。特に「ファルケンベルク」は俗称「絵の具 箱ジードルンク」と称され、構法こそ伝統的な煉瓦造、勾配屋根の 形式だったが、色彩による各戸の塗り分けを行っていて表現主義建 築の一例ともされる。「ジードルンク覚え書」にはそのことが誇ら しく記述されていて、自信作の一つであることが窥われる ${ }^{12) 。}$

ファルケンベルクの小規模な住宅団地の建設は以下のようなもの だったという。

「前もって関係者たらのあいだで何回も大会を開き、平面計画、 多数の図面、模型等を批判し、またこれについて討論もし、組合員 の大多数が究極的な決鴙を下した。」13)

各家屋に色彩を施すことも組合員に対して提案されており、タウ トは自ら反論を受けな汸ら住民との協議を行ったことを記している。 ドイツ田園都市協会とは、実際のところ、住宅貯蓄組合のようなも のであり、将来の施主となる労働者が組織したものだったが、その ような組織が主導し、建築家が建築空間の形を提案して直接協議す るという大衆民主主義時代の集合住宅の設計プロセスがこの時代に 試みられたこととなる。すでにドイツにおいてはへレラウ(Hellerau)、 
シュターケン(Staaken)といった田園都市が実現していたが、前者が 芸術家村の面影を残し、後者が産業都市的な存在であり ${ }^{14) 、 そ れ に ~}$ 対し、ファルケンベルクは住民主体の組合方式、自主財源であって、 大衆の時代における住宅団地の先駆的な事例のひとつとなった。

このように、1910 年代は伝統的な住宅形式を中世集落風に集めた イギリスの田園都市をモデルに、色彩建築などの実験的な要素を加 味しつつ、住民主体の組合組織と共同してローコストの住宅団地の 新しい形式を試みた、ジードルンクの萌芽的な段階だったとするこ とができる。

\section{2-2. 1920 年前後のユートピア構想の段階}

「ジードルンク覚え書」では建築事業の専門的、奏務的な側面に 重点が置かれており、第一次大戦直後の理想論を展開した時期のこ とは書かれていない。タウトは 1920 年前後の表現主義的ユートピ ア構想を展開した時期のことについて、それ以後、沈然しているか のように見える。しかし、タウトのジードルンク造形観の変遷の構 図を確認する際にはこの部分は重要な意味を持つ。

著書『都市の解体 ${ }^{15)}$ 』(1920 年)は夕ウトのユートピア思想の中で ジードルンクがどのような位置づけをされていたのかを知ることの できる資料である。ここで言う「都市の解体」とは、大都市におけ る居住環境の悪化に対し、田園での分散した居住形式を推賞するも のであり、独特の集合形式による居住施設がラフなスケッチで提案 されていた。

同書第 2 図は「労働共同体(Arbeitsgemeinschaft)」と題され、花び らのような構成の中央に 5 棟の工房が建ち、周辺に点々と住宅が配 置される。ここには 5～600 人が住み、手仕事と田園の労働で生計 を立てる。さらに同書第 3 図は「農業労働共同体 (Landarbeitsgemeinschaft)」と題され、納屋や廐舎を共有する集団が農業労働で 生計を立て、他方に円環状に長屋型の集合住宅が配置される。同書 第 4 図は「必要な労働センター(Arbeitszentren)」と題され、港と工 場群を核とするやや都市的な景観が示されるが、近代都市の高密で 非衛生的な市街地は排除されている。居住には自然や大地との接触 が望ましいとして田園住宅地が放射状に展開するのである。そこに はソ連で試みられ始めた集産主義の新しい社会構造の影響が見られ るが、それが伝統的で有機的な農村集落の面影で包まれ、まるで全 体が拡散し、ネットワーク化した生き物のように再編成された。そ れはタウトの思い描く有機的な理想社会像だったと言えよう。

ここには伝統的な住宅形式でなく、菱状の鋭角的な表現主義的な 住宅形態が示されており、また集落状の集合形式は伝統的な農村の 自然発生的な形態ではなく、プリミティブな生命体のような一定の パターンを持つ形態で示された。1920 年前後のタウトは表現主義的 な造形を通して建築物を生命体に擬することをしばしば行っている が、これは同様の有機体アナロジーと見なしてよいと思われる ${ }^{16)}$ 。

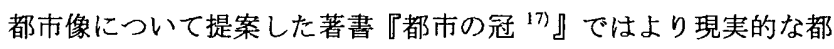
市像が示された。それは直径 $7 \mathrm{k} \mathrm{m}$ の冈形をなす都市であり、中央 にひとびとの精神的な支柱となる象徵的な「都市の冠」の大規模な 建築物が墕え、周辺市街地からだんだんと盛り上がる求心的な都市 景観を示した。その明快な都市構造はそもそも新都市を設計する機 会がなければ実現できるものではないが、住宅地の、菜園を持つ長 屋型の細長い連続住宅をゆったりと展開させる形式は、その後の現
実のジードルンクに影を落とすことになる。

タウトの 1930 年代の文章にはこの時期の理想主義的な言葉遣い はほとんど見られず、かろうじて「都市の冠」の言葉が都心の高層 建築物を指す言葉として使われているに過ぎない ${ }^{18)}$ 。しかし後述す るように、その空間的、造形的なイメージは潜在化して継承され、 違った形で生き続けていると見なすべきと思われる。

\section{2-3. 1920 年代の大都市郊外住宅団地の空間形態形成の段階}

タウトの「ジードルンク賞え書」には、1924〜32 年までの期間が ドイツにおけるジードルンク建築の学習期だったと記してある ${ }^{199}$ 。 それは戦後の混乱期を過ぎた景気回復期に始まり、ナチスによる近 代派の追放の時期で終わっている。実際、タウトはこの時期に、特 にベルリンで多数のジードルンク建設に関与した。それは単なる設 計ビジネスではなく、伝統的な住宅の観念から古い居住観へと変え させるための闘いの過程でもあったことを彼は述べていた。

1924 年景気回復の年であるだけでなく、「ゲハーク」(GEHAG : 共益住宅・貯蓄・建築株式会社 ${ }^{20)}$ ) が設立された年として歴史的な 意味があった。これは労働組合や住宅貯蓄組合が連合して労働者の 住宅供給を図ろうとする企業体であり、二十世紀の住宅福祉政策の 象徵的な存在でもある。初代の理事長となるマルティン・ヴァグナ 一(Martin Wagner)はベルリン市都市建設課長(Stadtbaurat)に就任し、 ベルリン市の都市計画や各種の開発計画、再開発計画を推進したこ

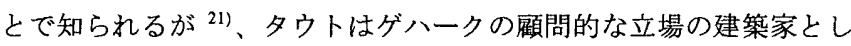
てヴァグナーと連携して、大多数のジードルンクの設計を手がける 22)。タウト自らは、この時期に 1 万 2 千戸を手がけたとしている ${ }^{23) 。 ~}$ 前述したように彼は日本におけるジードルンク建設に必要なものと して「組合」に言及しているが 24)、それは 1920 年代の成果が、労 働者の自主財源、自律的組織により、住居の形態や居住空間の構造 を自己決定するというシステムを形成するのに成功したからである。 タウトは別の論文で、集団の意思を精神的な形に表現する「組合建 筑(Genossenschaftarchitektur)」なる概念も唱えていた ${ }^{25)}$ 。

その経過を通して、かつての牧歌的な田園都市の形式は大きく変 化する。大都市郊外に大規模に展開する「大ジードルンク (Großsiedlung)」は、居住関連の共用施設を含む、一定の自律性も有 した大型の住宅団地となる。特に伝統的な勾配屋根から陸屋根への 変更については社会的な論争が続くが、タ.ウも経済的な陸屋根を 前提に居住空間の形態の開発と説得に努力したことを記している。

ジードルンクの造形という観点からは、この時期にタウトの建築 デザインは特に以下の二点に整理できる。

\section{a ）表現主義的造形手法の改変}

タウトの建築デザインは一般に表現主義で一括されるわけだが、 1920 年代のジードルンクのデザインにはそれがあまり認められない。 表現主義の個性的で複雑、また感性豊かな造形はローコストの労働 者住宅においてはむずかしいため、タウトはそれに対応した造形シ ステムを開拓する努力をする。それは一方でジードルンク全体の配 置計画における大きなスケールでの象徵的デザインに、他方で壁面 の彩色による環境デザインに結晶した。

「馬蹄形ジードルンク (Hufeisen-Siedlung)」の俗称で著名なブリッ ツ(Britz)大ジードルンク(1925-33 年)はタウトの思想を代表する建築 作品とされるが、そこでは中庭を团む馬蹄形の長大な集合住宅で求 
心性をつくり、バロック的な対称性を基調にデザインされた。その ネオ・バロック的な象徵的デザインの傾向は『都市の解体』でも一 部で似たものが提示されていたが、当時注目されていたカミロ・ジ ッテの都市造形理論にルーツを辿ることができ、敷地特性や緑地環 境との関係も配虑されていた ${ }^{26)}$ 。この大きな馬蹄形については「大 衆の装飾 ${ }^{27}$ 」という批評があり、前述の夕ウト独自の「組合建築」 という概念の建築的表現とも言える。この馬蹄形は表現主義的な自 己主張の一面も有するが、周辺の集合住宅群をまとめており、広域 の住宅団地の有機的な構成の核として位置づけられた。表現主義の デザインは一種の総合的な社会空間のデザイン手法に発展している わけである。求心的で情熱的な表現主義デザインは、一定の統合性 を保持しながら、分散的な要素群をまとめる構成デザインの手法に 向かって変化してきていることになる。

\section{b）分散化・多様化のデザイン手法の開拓}

「オンケル・トムス・ヒュッテ(Onkel Toms Hütte)」と称されるツ ェーレンドルフ(Zehlendorf)大ジードルンク(1926-32 年)では、長屋 型の住棟群がやや崩れた平行配置をなしているに過ぎず、象徽的、 統一的なデザインは見られない ${ }^{28)}$ 。建築家としてのタウトのデザイ ン的な関心は、機械的な配置計画とならないよう配虑し、周囲の森 の中にとけ込み、自然な空気の流れを感じさせる住棟配置とし、プ ロムナードや、特に住棟端部のちょっとした変化によって、何気な いながらも個性的な街角をデザインすること、などだった。このよ うな発想をタウトは「屋外居住空間(Außenwohnraum)」の概念で説 明しており、外部空間設計という理念の先駆的な事例となった ${ }^{29) 。}$

そのデザイン方法は、中心性を嫌う分散的デザイン、統一性を否 定した多様性のデザインと見ることができる。しかし、考虑に入れ ておくべきことは前述の『都市の冠』において示された都市景観に は、中心部こそ強い求心性を示すが、周縁部の住宅地には細かな変 化を加えて分散化する傾向が示されたことである。このジードルン クはそのような周縁部の一例として位置づけされたことになる。

「ジードルンク覚え書」には自然地形や住み心地に配慮する人間 的な感覚を排除してしまった近代的な科学的合理性を批判する文面 が随所に見られる。彼は太陽光線から一律に方位を決めた完全な平 行配置による「列状建築(Zeilenbau)」の単調さ、伝統的な手仕事の 煉瓦造からの転換を図った「機械化構造法 (mechanisierte Konstruktions-methode)」の硬直を批判し、また名指しこそしなかっ たが、グロピウスが関与したベルリン郊外ハーゼルホルストの実験 住宅団地を悪しき例として挙げた ${ }^{30)}$

タウトの居住空間のイメージは、同じく経済合理性や科学的合理 性を唱えつつも、一律の造形原理に定式化することを否定し、多様 化を図ることだった。中心性を持ちつつ分散化させる形態イメージ は、個人を尊重しつつ組織化を目指す「組合」の社会形態と同じ構 造を持つものと考えられていたと言える。

\section{1930 年代のジードルンク造形観}

\section{3-1.『建築芸術論』におけるジードルンク造形理論}

\section{a)「釣合」理論の適用}

前述した『建築芸術論』(1938 年) において、タウトは第二章で

「釣合 (Proportion)」を論じ、自らが行った設計の方法を紹介しつ つ、建築設計の究極の目標がそこにあることを説いている。その言
葉はウィトルウィウス建築論に遡る古典主義の重要概念であるため、 近代主義者であるタウトが古典主義に復㷌し、保守化したことの一 端を示すものとして批判的に見られることもある。確かにこのこと は表現主義の大胆で刺激的な形態を好んだタウトにしては奇異に感 じられが、実は、その概念を説明するのにジードルンクの設計方法 が例に引かれていて、ここで注目しておくべき必要がある。

タウトは"Proportion"の言葉を単なる「比例」とは解釈せず、以下 のように説明した ${ }^{31) 。}$

「全体が見事に分割(Teilung)せられているとき、我々は『全体が 美しい鈎合(Proportionen)をもっている』と言う。それだから英語で Proportion というと、『割合 (Verhältnis)』だけでなく『均整 (Ebenmass)』をも意味する。これはフランス語でもドイツ語でもま ったく同様である。しかし建築の領域では、この語は美しい分割、 量的調和(Harmonie der Massen)、つまり均整という意味でもちいら れなければならない ${ }^{32}$ 。」

実際のジードルンク設計についてタウトは以下のように語る ${ }^{33)}$ 。 設計においては、まず戟地にかかわる内的、外的条件、居住者の 属性等を㽎酌し、住居の样式や規模、数など建築的な与件を整理し、 合理的な解決策を考案し、図面にしておく。しかしそれは「科学 的」な次元に過ぎず、諸绦件を整理した後、しばらく感情の高まり を待つこととなる。そのうちに「ほとんど無意識に図を引き始め る」ことになり、「手のみが紙上を縦横に馳せて抽象的な線を描き、 街路や街区を配分し、あるいは家屋を配置する。」いうのである。

また、「図面の無味乾縜なことは大きな危険である。まして同じ 型の住居を数多く、時には数百戸も同時に建築するとなると危険は ますます增大する。」そこで、建築家は図面を机の前にしばらく貼 って、睱にまかせて思案を繰り返す。そうするうちに、「五ミリな いし十ミリぐらい前後左右に動かしたり、また『些細な点』に変更 を加えたとしても全体としては赛用的ないし技術的になんら差し障 りのないことがわかってくる。そうして硬直した形式に摇らぎが 加えられ、単なる機械的な設計ではなくなる。「まず頭脳が一切の 実用的な前提を十分にこなさなければならない。そうすれば感情は おのずから湧き上がるのである。」

つまりタウトにとっての理想的な設計は、まずは課題に科学的、 合理的な解決をつけ、その後は芸術家的な感覚の遊技にまかせ、非 合理的とも言えるやり方で最終案に至るのである。「釣合」とは、 結局のところ数字で明示される比例秩序などではなく、部分と全体 が調和し合ったと直観される状態を指す。

このような建築論が、近代合理主義が混迷に陥る 1930 年代に書 かれていることに注目しておかなければならない。伝統や古典に回 帰する社会風潮の奥に、近代主義がより高度の理論に発展する方向 が見出されるからである。社会システムと建築空間のシステムを同 時に思索していたタウトは、新種の建築の課題に取り組みつつ、部 分と全体の間に、改めて生気ある関係を再編しようとしたのである。

\section{b）機能主義批判と有機的造形への転換}

『建築芸術論』では第五章で「機能(Funktion)」を取り上げ、詳細 に検討している。ジードルンクに関しては、例えば 1925 年頃にド イツでもてはやされた太陽光線一点張りの機能理論は問題がある、 土地利用効率を理由とした高層化は心理的に反撥するだけでなく、 「釣合」の観点から批判すべきである、計算にもとづく科学的方法 
も建築物が完成すると失望することが多い、といった批判が加えら れた ${ }^{34)}$ 。「ジードルンク覚え書」でもより具体的に同様の趣旨のこ とが述べられていたが、ここでは「釣合」の観点から批判がなされ る点が異なる。

タウトは 1930 年頃の短期間、シャルロッテンブルク工科大学で ジードルンクについて教えたが、そこでの経験から「列状建築」、 「片廊下型(Laubenganghaus)」、「高層建筑(Hochhaus)」の流行に追 随する学生を批判し「機能の相対性」を説いたことを記している ${ }^{35) 。 ~}$ また、『建築芸術論』の第四章「構造(Konstruktion)」においては、 「鈎合」の理論に言及しつつ、ベルリン・ノイケルンのジードルン クの写真を挿入して、長大な集合住宅壁面をわずかに「湾曲」させ たこと、またペシュケン編ドイツ語版では「馬蹄形ジードルンク」 の写真も載せて、微妙な湾曲と段差を与えたことに注目させている 36)。夕ウトが単調な機能主義的造形に対する対案としたものは、こ ういった細やかな変化を加えて均衡させる形式だったのであり、同 じく機能主義批判を行ったといっても、それは伝統回帰を唱える保 守派とははっきりと異なる第三の道だった。『建築芸術論』の中で、 この例示は雪舟の花鳥・山水画を図示し、論及した後に説かれた ${ }^{37)}$ 。 つまり東洋芸術の変化に富み、生気のある形態群に対して覚えるの と同じ感覚で、ジードルンクの居住環境を造形していることとなり、 そこに独特の有機的造形への転換が唱えられていることになる。

\section{3-2. ジードルンク関連設計案に見る有機的造形への模索}

ドイツを離れた 1930 年代に、タウトはジードルンク作品を実現 できなかったが、関連する試みはあり、またベルリン時代とは若干 異なる独特の考え方や姿勢を示した。慣れ親しんだドイツとは異な る環境においても、この時代の問題をつねに頭に置きつつ、タウト は柔軟に独自の建築観を育んだことがそこに確認できる。

\section{a ）ソ連での都市・住宅建築の指導}

タウトは自ら社会主義に傾倒した建築家であり、「新ロシア友の 会」の会員として、1926 年に講演旅行をし、その際、モスクワの住 宅政策の指導者のポストに請われている。ソ連の文化運動の指導者 だった A.V.ルナチャルスキーがベルリンを訪問した際にブリッツの 「馬蹄形ジードルンク」を見せ、社会主義の労働者住宅団地の模範 として感動させてもいた ${ }^{38)}$ 。1932 年にはモスクワの建築設計組織 の指導者の地位を得てモスクワに移住し、大型集合住宅建築の案な どを残しているが、ジードルンクの設計案は知られていない ${ }^{39)}$

ソ連にはエルンスト・マイ、ハンネス・マイアー、ハンス・シュ ミット、マルト・シュタムらが新都市やジードルンクの建設に携わ っており、ドイツ周辺の建築家たちがソ連の社会主義下において新 しい居住環境の実験に意欲を示していた ${ }^{40)}$ 。タウトは「大モスクワ 市」都市計画の設計競技に外国人審查員として招かれたが（1933 年)、その際にドイツ人建築家たちの応募作品について、たとえば エルンスト・マイの機械的な配置計画を批判したりしたという ${ }^{41)}$ 。 タウトは「ジードルンク覚え書」に、経緯は明らかではないが、ソ 連の当局もついに 1932 年には「列状建築」を禁じるに至ったとも 述べている ${ }^{42)}$ 。外国人を敬遠し始めたソ連にあって、タウトもすぐ に失意のうちに去ることとなるが、彼が社会主義政権のもとで機能 主義のみではない居住環境のあり方を求めたことは確かである。

b）日本での表現主義的ユートピア・イメージの適用
1933〜36 年の日本滞在時には建築設計の仕事に恵まれなかったが、 ジードルンクに関連する仕事として、唯一、大阪電軌株式会社の委 託で作成した「生駒山嶺小都市計画案」(1933 年)があった ${ }^{43)}$ 。そ えは電車の終着駅に遊園地と住宅団地を組み合わせた民間資本の不 動産開発計画だった。中心をなす遊園地の塔と大型の複合建築は、 表現主義期の「フォルクヴァング学校設計案」(1920 年)にルーツを 遡ることのできる非対称の複合的デザインを示し、全体景観は山頂 に展開して『アルプス建築』や『都市の解体』の有機的な集落風景 のスケッチを連想させる。緑の中に分散配置させた一戸建て住宅群 には和風の建築スタイルが取り入れられていた。この時期に、既に 忘却の彼方かと思われた 1920 年前後の表現主義的ユートピア・イ メージが日本的な風景を背景に適用され、復活したかのように見え ることは注目される。そこでは表現主義のとげとげしさは排され、 代わって多様な要素をまとめ、丘陵地の自然な景観に統合する、有 機的な構成デザインの手法に還元されてきていることが認められる。

\section{c）トルコでの設計教育における住宅団地例}

1936〜38 年の短いトルコ滞在期に、タウトはイスタンブールの芸 術アカデミー教授となり、学生の設計課題を指導した。そこから二 つのジードルンク計画案があったことが確認されている。そのうち のひとつ、アンカラ市の官公庁地区に提案された職員住宅団地の学

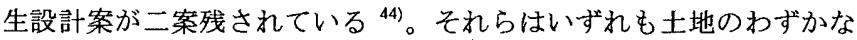
起伏に対応させて変化させてあるが、菜園を備えた連続住宅群、平 行配置だが一部に凹凸、雁行を加えてあるといった特徽を示し、例 えばツェーレンドルフの大ジードルンクで試みられたもののヴァリ エーションと見なしてよい。ただ、タウトはトルコ国会議事堂コン ペ（1937 年）に応募して、丘陵上の敷地を利用して「都市の冠」型 の都市景観を提案したが ${ }^{45)}$ 、この計画案はその縁に位置する計画で あるため、タウトは関連を意識していたと見なすべきであろう。統 合的な全体景観と部分における微妙な変化や複雑化という構図は、 タウトの確信的な都市景観イメージとなっており、このジードルン ク計画案もその構図の中で位置づけできる。

以上のように、タウトにとって 1930 年代は自らのジードルンク 建設活動をより幅広い視点から振り返り、理論的に整理すると同時 に、一定の修正を加える時期となったとすることができる。そのン 連、日本、トルコでの表れ方は一見まとまりがないが、そこに硬直 的な図式化を否定し、地域の固有性や多様性を許容しつつ、部分と 全体の有機的な関係性の理論をもって統合的な都市空間組織を提示 しようと試みていたタウトの造形観の新しい段階が確認できる。

\section{4. 総括}

以上のように、タウトの 1910 年代から 1930 年代におけるジード ルンク造形観の変遷を、三つの段階と 1930 年代のより達観した段 階に整理することができた。すなわち、1910 年代にドイッにおいて 盛り上がっていた田園都市運動を通しての大衆民主主義時代の居住 観の形成段階、1920 年前後の表現主義的ユートピア構想を背景にし た集合居住イメージの提案の段階、1920 年代における多数の実作を 通しての、分散的な大都市郊外住宅団地の空間形態確立の段階、そ して最後に、1930 年代の外国での、多様な要素を柔軟に受け入れつ つ統合する有機的な造形手法を模索した段階である。

1930 年代においてタウトが抱いたジードルンクの理想は、機能主 
義的設計方法のもとに単調化してきていた住宅地環境を批判的に見、 住民集団の自主性を引き出しつつ、造形的には多様性や变化を含み、 自然や地域性、伝統性と対話し、部分と全体の間の細やかな関係性 を演出した、より有機的で生命感のある居住空間の形式にあった。 そこに見えるのは田園都市理論を基盤にしつつも近代化一踏み出し、 表現主義的ユートピア思想を自ら批判的に継承し、また多数のジー ドルンクの実作を通して詳細なデザイン手法の効果を吟味してきた、 より包括的な都市空間組織の造形家としてのタウト像である。

1930 年代のタウトの活動は、国を追われた不遇の建築家、あるい は古典主義に回㷌した変節の近代主義者として見られ、あまり高い 評価がなされないことがあるが、幅広い視野を持って独自の建築、 居住環境のデザイン方法を思索し、進化を続けていた近代建築の思 想家として改めて評価できよう。

\section{謝辞}

本研究仙平成 14 年度科学研究費補助金基盤研究(C)(2) 課題番号 14550637 「近代合理主義と伝統的有機性の対立と調整に関する空間シス テム論的研究-1930年代のドイツ近代建築家の国外での活動を事例 としてー」の研究成果の一端をなす。

\section{註}

1）包括的な文献として以下のもの参考にした。Kurt Junghanns: "Bruno Taut, 1880-1938 : Architektur und sozialer Gedanke", 3. Aufl., Leipzig, 1998. "Bruno Taut, 1880-1938 : Architekt zwischen Tradition und Avantgarde", herausgegeben von Winfried Nerdinger, Kristiana Hartmann, Mtthias Schirren, Manfred Speidel, Stuttgart etc., 2001. マンフレッド・シュパイデル，セソン美術館編著，『ブル 一ノ・タウト 1880-1938』，トレヴィル，1994 年。特に、第8 章「都市 と建築の社会主義 : ジードルンク」, 209-240 頁

2) Franziska Bollerey, Kristiana Hartmann, 'Bruno Taut - Vom phantastischen Ästheten zum ästhetischen Sozial(ideal)isten', in: "Bruno Taut 1880-1938", Berlin, 1980,pp.15-85.F.ボレリ，K，ハルトマン著, 生松敬三訳,「幻視 的美学者から美学的社会 (理想) 主義者へ」,所収二土肥美夫他著『ブルー ノ・タウトと現代一「アルプス建築」から「桂離宮まで」一』，岩波書 店,1981 年,63-200 頁。

3) Norbert Huse, "Siedlungen der zwanziger Jahre - heute ; Vier Berliner Großsiedlungen 1924-1984“, Berlin, 1984.

4) Winfried Nerdinger, "Ein großer Baum muß tiefe Wurzeln haben" Tradition und Moderne bei Bruno Taut', in: "Bruno Taut ", 2001, pp.9-23. そこでは、「生き物 (atmende Wesen)」というキーワードの他、一部に「有機的(organisch)」の 語も見られる。Kristiana Hartmann, 'Bruno Taut, der Architekt und Planer von Gartenstädten und Siedlungen', in:"Bruno Taut”, 2001, pp.137-155.

5) Bruno Taut, 'Siedlungsmemoiren', in: Akademie der Künste, "Bruno Taut 1880 1938”, Berlin, 1980, pp.204-211.「ジードルンク覚え書」,ブルーノ・タウト 著,藤島亥二郎訳『建築論集』,育生社弘道閣，1943 年, 271-308 頁;「ジード ルンク覚書」,ブルーノ・タウト著,上野伊三郎訳、『現代の建築』,育生 社,1948 年,121-164 頁 ; 「ジードルンク覚え書」,ブルーノ・タウト著,篠田英 雄訳目続 建築とはなにか、,鹿島出版会,1978 年,91 頁。本論文では訳書を 参考にするが必要に応じてドイツ語原文から独自に訳出して修正を加える。

6) 同書,390 頁。訳者の解説文中。

7）『続建築とはなにか』,75-77 頁。

8）「ジードルンクス・バウ (集落計画)」，『建築論集』，233-270頁。『現代の 建築』, 165-204 頁。

9）参照=『続 建築とはなにか』，91 頁。以下の原文から改訳。Akademie der Künste, "Bruno Taut", p.205.

10)「日本とジードルンク」, タウト著,篠田英雄訳『続 建築とはなに か』,116-123 頁。引用は 117 頁。

11）ブルーノ・タウト著,篠田英雄訳、『建築芸術論』,岩波書店,昭和 37 年（初 版：昭和 23 年)。Tilman Heinisch und Goerd Peschken (Hrsg.), Bruno Taut: "Architekturlehre", Hamburg, 1977. トルコで 1936〜37 年に書き下ろし、ト ルコ語訳＝ Bruno Taut, "Mimari Bilgisi", Istanbul, 1938. そもそも 1935〜36 年に日本で書かれた『建築に関する省察』“Architekturüberlegungen”が元 となる。和訳所収：タウ卜著,篠田英雄訳『建築とは何か』,鹿島出版 会,1974,pp.9-182。

12）『続建築とはなにか』,91-92 頁。

13）『続建築とはなにか』,91 頁。
14）参照=Julius Posener, "Berlin auf dem Wege zu einer neuen Architektur : Das Zeitalter Wilhelms II." München, 1979, 'Die deutsche Gartenstadtbewegung', pp.264-280.

15) Bruno Taut, "Die Auflōsunis der Stādte oder Die Erde eine gute Wohnung, oder auch : Der Weg zur Alpine Architektur.“ Hagen i.W., 1920.

16）そのことは著書『宇宙建築師』において最も顕著である。Bruno Taut, "Der Weltbaumeister. Architekturschauspiel für symphonische Musik." Hagen i.W., 1920. そこに扔ける有機体アナロジ一を通してのタウトの有機的建築観の 傾向については、杉本俊多「ブルーノ・タウト、建築の解体と蘇生」、『ユ リイカ』1984 年第 16 巻 6 号,85-95 頁を参照されたい。

17) Bruno Taut, "Die Stadtkrone", Jena, 1919.

18）「西洋の建築と日本に対「るその意義」(1934 年)の中において。『続 建 築とはなにか』,79 頁。

19）住宅経済においても、1924 年、1930 年が区切りとなった。参照二 Mechthild Stratmann, 'Wohnungsbaupolitik in der Weimarer Republik', in: Neue Gesellschaft für Bildende Kunst, "Wem gehört die Welt - Kunst und Gesellschaft in der Weimarer Republik“, Berlin, 1977, pp.40-49.

20) Gemeinnützige Heimatstätten-, Spar- und Bau- Aktien-Gesellschaft.

21）ヴァグナーについては、主に以下を参照。Ludovica Scarpa, “Martin Wagner und Berlin : Architektur und Städtebau in der Weimarer Republik", Braunschweig, 1986; Posener, op.cit., pp.289-318 ('Martin Wagners Dissertation').

22） 参照=Wolfgang Schäche(Hrsg.), “75Jahre GEHAG : 1924-1999”, Berlin, 1999.

23）ゲハーク資料によれば、1931 年度段階での着工住宅戸数は、アパートメ ントが 6082 戸、単家族住居（一戸建て住宅·連続住宅）が 2358 戸、合計 8440 戸となっており、タウトが大多数に関与している。Ibid., p.34.

24）「日本とジードルンク」，『続建築とはなにか』,121 頁。その他。

25) Bruno Taut: 'Genossenschaftsarchitektur', in: "Die Wohnungswirtschaft", 3,1926, H.1, pp.12-14. 抄録=Akademie der Künste, "Bruno Taut", p.212.

26) Camillo Sitte: "Der Städtebau nach seinen künstlerischen Grundsätzen", 1. Aufl. Wien 1889 .

27）この評言は映画批評家クラクア一の著書の題名から来ている。Siegfried Krakauer, "Das Ornament der Masse", Frankfurt a.M., 1964.

28) Helge Pitz, Winfried Brenne, "Die Bauwerke und Kunstdenkmäler von Berlin, Bezirk Zehlendorf, Siedlung Onkel Tom, Einfamilienhäuser 1929, Architekt Bruno Taut", Berlin, 1980

29) Bruno Taut, 'Der Außenwohnraum. Zur stådtebaulichen Gestaltung der Gehag Siedlungen', in: "GEHAG-Nachrichten", 2,1931,Nr.1/2, pp.9ff. 抄録=Akademie der Künste, "Bruno Taut", p.224.

30)『続 建築とはなにか』,109-111 頁。

31）本論文中での引用は、箱田訳をもとに一部加筆修正、表記を現代語化。

32)『建築芸術論』,20頁。Peschken (Hrsg.), op.cit., p.38.

33）以下の引用は、『建築芸術論』,20-24 頁。Peschken (Hrsg.), op.cit., pp.38-41. より抽出。この部分には:ハルトマンも同様の評価をしている。参照= Hartmann, op.cit., 2001, pp.148.

34）『建築芸術論』,179,186-192 頁。Peschken (Hrsg.), op.cit., pp.133,138-142.

35)『建築芸術論』,190-91 頁。Peschken (Hrsg.), op.cit., pp.140-141.

36）『建築芸術論』,150-51 頁, 図 49。Peschken (Hrsg.), op.cit., p.116, 197, Abb.67,68..

37) 『建築芸術論』,149-50 頁, 図 47,48。 Peschken (Hrsg.), op.cit., pp.116, 197, Abb.65,66

38) Barbara Kreis, '》 Geschmacksfragen sind soziale Fragen - Vom Sozialismus des Kunnstlers zur sozialistischen Realităt 《, in: Nerdinger, etc. (hrsg.), op.cit., p.158.

39）参照=シュパイデル,セソン美術館編著,前掲書，「住宅街区のためのファ サード案」図X-12,13。

40）参照=Christian Borngräber, "Ausländische Architekten in der UdSSR: Bruno Taut, die Brigaden Ernst May, Hannes Meyer und Hans Schmidt", in: Neue Gesellschaft für Bildende Kunst, op.cit., pp.109-137.

41）クライスの研究を参照。Kreis, op.cit. p.162-165. またタウトは、日本に 向かうシベリア鉄道の列車からノヴォシビルスクに近づいたときに見た 「四階建ての家を列状に涼らべた、フランクフルト式」のジードルンクを

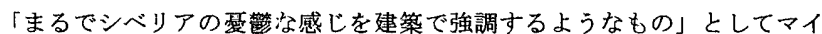
のフランクフルトでの仕事を当てこすっている。参照＝ブルーノ・タウト 著,吉田鉄郎訳, 「日本への旅」，『建築と芸術』所収,雄鵎社,1952 年,174 頁。 42）『続 建築とはなにか』,110頁。

43）東京大学所蔵のスケッチ。参照ニシュパイデル,セソン美術館編著,前揭 書,232-235 頁。

44）参照 = Junghans, op.cit., pl.368-369. Bernd Nicolai: "Moderne und Exil Deutschsprachige Architekten in der Türkei 1925-1955“, Berlin, 1998, pl.120-121.

45）参照=Nicolai: op.cit., pp.136-137. トルコ国会議事堂コンペ案については、 Junghanns: op.cit., pl.367. 等を参照。 